\title{
Moraine-dammed lake distribution and outburst flood risk in the Chinese Himalaya
}

\author{
WANG Shijin, QIN Dahe, XIAO Cunde \\ State Key Laboratory of Cryospheric Sciences, Cold and Arid Regions Environment and Engineering Research Institute, \\ Chinese Academy of Sciences, Lanzhou, China \\ Correspondence: Wang Shijin <xiaohanjin@163.com>
}

\begin{abstract}
To better understand the risk of disasters due to glacial lake outburst floods (GLOFs), we synthetically analyze the spatial distribution and evolution of moraine-dammed lakes and potentially dangerous glacial lakes (PDGLs) in the Chinese Himalaya. Our county-based assessment of GLOF disaster risk combines PDGL outburst hazard, regional exposure, vulnerability of exposed elements and adaptation capability (risk management) using the analytic hierarchy process. We synthetically analyze the disaster risk using the weighted comprehensive method. Remote-sensing data show there are 329 moraine-dammed lakes $\left(>0.02 \mathrm{~km}^{2}\right.$; total area $\left.125.43 \mathrm{~km}^{2}\right)$ in the Chinese Himalaya, of which 116 (total area $49.49 \mathrm{~km}^{2}$ ) are identified as PDGLs. The zones at highest risk of GLOF disaster are mainly located in Nyalam, Tingri, Dinggyê, Lhozhag, Kangmar and Zhongba, in the mid-eastern Himalaya. Lowest-risk zones are located in the eastern Himalaya. On the county scale, Lhozhag and Lhunze have the highest hazard degrees and exposure, while Zhongba and Zando have the highest degree of vulnerability and lowest adaptation capacity. Our regionalization results for GLOF disaster risk are consistent with the distribution of historical disaster sites across the Chinese Himalaya.
\end{abstract}

KEYWORDS: applied glaciology, glacier hazards, glaciological natural hazards, subglacial lakes

\section{INTRODUCTION}

The cryosphere is highly sensitive to global warming (Qin and others, 2005), and mountain glaciers have retreated and thinned rapidly in recent decades, in response to regional change. This has led to the formation of new glacial lakes, the expansion of existing glacial lakes (Yao, 2010) and increased potential for glacial lake outburst floods (GLOFs) (Clague and Evans, 2000; Sakai and others, 2000; Nayar, 2009; Benn and others, 2012; Worni and others, 2012). The three main types of glacial lake are moraine-dammed, glacier-dammed and glacier erosion lakes. Moraine-dammed lakes are formed behind moraines after glacier retreat, and GLOFs following dam collapse have frequently been reported in the Himalaya, Peruvian Andes (Cordillera Blanca), Chilean Patagonia, Canadian Rockies, Chinese Nyainqêntanglha and elsewhere (Vuichard and Zimmermann, 1987; Clague and Evans, 2000; Richardson and Reynolds, 2000; Mool and others, 2001; Singh and Singh, 2001; Carey, 2005). Moraine-dammed lakes are impounded between the end-moraine complex and the vanishing glacier tongue. Some have high outburst probabilities due to unconsolidated dam material, unstable dam geometries, snow-ice-rock avalanches and other types of landslides caused by, for example, earthquakes and permafrost degradation of dams that contain dead or other subsurface ice (McKillop and Clague, 2007; Frey and others, 2010; Haeberli, 2013; Worni and others, 2013). Morainedammed lake outbursts are often accompanied by mudslides, landslides and other secondary events, and have caused severe loss of life and destruction. In contrast, glacierdammed and glacier-erosion lakes are relatively stable and have less disaster potential (Korup and Tweed, 2007). Glacier-dammed lake outbursts occur mainly in the Karakoram, eastern Hindu Kush and Alaska (Iturrizaga, 2009).

High-mountain areas worldwide are especially vulnerable to global warming impacts. Local communities and cities are often potentially within reach of GLOFs. Though GLOFs are low-frequency events, resulting disasters have caused enormous loss of life and damage to livestock, property, infrastructure (e.g. hydropower, mining, roads, bridges), natural resources (grassland, forest, cultivated fields, etc.), agriculture and animal husbandry, tourism and the human environment in downstream regions. GLOFs are therefore considered the most important glacier-related hazard in terms of direct damage potential (Osti and Egashira, 2009). The main areas affected by GLOF disasters are the Karakoram, the central-eastern Himalaya and the Cordillera Blanca, Peru (Mool and others, 2001; Carey, 2008): 35 destructive outburst floods have been recorded in the Karakoram in the past 200 years (Ashraf and others, 2012), the Nepalese Himalaya have experienced 15 GLOFs, with an outburst flood occurring on average every 3 years, since the 1960s (Richardson and Reynolds, 2000; Kattelmann, 2003), and >21 GLOF disasters, killing nearly 30000 people, have been reported in Peru's Cordillera Blanca during the past 65 years (Carey, 2005, 2008). There have also been 53 cases of lakes draining in Chilean Patagonia from 1896 to 2010, and their frequency has increased in recent years, with five major GLOFs during 2008/09 in the Northern Patagonia Icefield (Dussaillant and others, 2010). Past records and statistical analyses show that at least 40 GLOFs have occurred in the Chinese Himalaya and Nyainqêntanglha ranges since 1935, at an average of one event per 2 years (Wang and Zhang, 2013). Classic examples of GLOFs are the bursting of Palcacocha lake, Peru Cordillera, in 1941 (Carey, 2005, 2008); Cirenmaco lake, Chinese Himalaya, in 1981; Dig Tsho lake, Nepalese Himalaya, in 1985; and Luggye Tso, Bhutan Himalaya, in 1994 (Kaltenborn and others, 2010). Recent outburst occurrences in the Cordillera Blanca at lake No. 513 in 2010 and low Artizon lake in 2012 (Carey and others, 
2012), in the Chinese Himalaya at Zhemaico in 2009, and in the Chinese Nyainqêntanglha at Cilaco lake in 2009 and Recireco lake in 2013 show that the threat of GLOFs will continue to require close scrutiny well into the 21 st century, as glacier retreat continues (Carey and others, 2012). In the next few decades, GLOF impacts will likely extend farther downstream as glaciers continue to retreat.

The Hindu Kush-Himalaya $(\mathrm{HKH})$ high-mountain area is the scene of high-frequency, major GLOFs. Past studies have identified $>8000$ glacial lakes and 209 potentially dangerous glacial lakes (PDGLs) in the HKH, 26 in Nepal (Ives and others, 2010), 24 in Bhutan (Kattelmann, 2003), 30 in India (Bajracharya and others, 2007), 52 in Pakistan (Ashraf and others, 2012) and 77 in China (Bajracharya and others, 2007). In a climate-warming scenario and active earthquake zone, these glacial lakes are prone to outburst. Unlike some other mountain regions (e.g. European Alps; Andes), the $\mathrm{HKH}$ is characterized by particularly large lake volumes and associated long outburst flood reaches. Most mountain communities in the $\mathrm{HKH}$ live in steep, narrow valleys downstream of glacial lakes and glacier-fed rivers, and depend on fragile ecosystems for their livelihoods. These communities lack resources and have limited capacity for disaster prevention and mitigation.

GLOF disasters result from both natural and social factors and their interactions. GLOF risks not only include the hazard of glacial lake outburst, but also involve the vulnerability and adaptation capacity of exposed elements. The hazard of glacial lake outburst can be defined as the product of outburst magnitude and outburst probability. Numerous empirical relations have been developed to estimate outburst probability, as well as the probable maximum discharge of outburst floods from morainedammed lakes, by using statistical and remote-sensingbased approaches, as well as field investigations (Fell, 1994; Huggel and others, 2004; McKillop and Clague, 2007). Previous studies have also focused on glacial lake distribution and on simulation of the evolution of GLOFs (Richardson and Reynolds, 2000; Huggel and others, 2002, 2004; McKillop and Clague, 2007; Mayer and others, 2008; Awal and others, 2010; Carey and others, 2012; Klimeš, 2012; Wang and others, 2012; Worni and others, 2013). GLOF impacts, regional exposure, the vulnerability of exposed elements, and adaptation capacity downstream have received less consideration or synthetic and quantitative assessment in previous studies (Schaub and others, 2013). Glacial lake outbursts can be difficult and expensive to control, but regional exposure and the vulnerability of exposed elements downstream can be reduced by improving adaptation capacity and risk management level. Some studies have begun to pay attention to the vulnerability and adaptation capacity of communities downstream of lakes of most concern (Mool and others, 2010).

In this study we consider 20 counties in the Chinese Himalaya as basic evaluation units, analyze the spatial distribution characteristics and evolution of morainedammed lakes and PDGLs, identify and analyze GLOF disaster risk, and establish a risk assessment system including glacial lake outburst hazard, regional exposure, the vulnerability of exposed elements, and adaptation capacity downstream. Finally, we quantify the degree of risk of GLOFs in the study area using GIS technology, the analytic hierarchy process and the weighted comprehensive method. The study is not only of significance for glacial lake outburst hazard analysis and assessment of the exposure and vulnerability of exposed elements, but also has important theoretical reference to resource use, disaster prevention and mitigation, and the establishment of an early-warning system in GLOF-affected areas.

\section{STUDY AREA}

The Himalayan mountain range spans China, Nepal, Bhutan, India, Pakistan, Kashmir and Afghanistan. The Chinese Himalayan region $\left(29^{\circ} 37^{\prime}-35^{\circ} 14^{\prime} \mathrm{N}, 74^{\circ} 35^{\prime}-95^{\circ} 03^{\prime} \mathrm{E}\right)$ is located in the south of the Qinghai-Tibetan Plateau and is characterized by rapid uplifting and intense geological activity. This area is affected by more GLOF disasters than any other worldwide.

Of the world's 14 highest mountains, 5 are located in the study area, including Mount Everest (Qomolangma) (8844 $\mathrm{m}$ a.s.I.), Lhotse (8516 $\mathrm{m}$ a.s.I.), Makalu (8463 m a.s.I.), Cho Oyu (8201 ma.s.I.) and Shishapangma (Xixabangma) (8027 ma.s.l.). The study area is bordered to the south by India, Nepal and Bhutan, to the west by the Gar Zangbo river, to the north by Gar, Dangque (Maquan) and Yarlung Zangbo, and to the east by Yarlung Zangbo (Brahmaputra River). The Chinese Himalaya extend $\sim 2400 \mathrm{~km}$ from east to west, with a width of $200-300 \mathrm{~km}$ and an average height of $6000 \mathrm{~m}$ (Fig. 1). The study region covers an area of $258983 \mathrm{~km}^{2}$, accounting for $21.54 \%$ of the land area of the Tibet Autonomous Region, and is administratively divided into 20 counties: Gar, Zando, Burang, Zhongba, Saga, Gyirong, Nyalam, Tingri, Dinggyê, Gamba, Yadong, Kangmar, Nagarze, Lhozhag, Comai, Cona, Lhunze, Nangxian, Main ling and Medog, in Nyingchi, Shannan, Xigaze and Ali Prefecture (Fig. 1). In 2012, it had a population of 394860 and a gross domestic product (GDP) of Yuan 6.19 billion, accounting for $12.80 \%$ and $8.90 \%$ of the total population and GDP, respectively, of the Tibet Autonomous Region.

The Concise Glacier Inventory of China (Shi and others, 2005) shows that there are 6472 glaciers in the Chinese Himalaya, with total area $\sim 8418 \mathrm{~km}^{2}$ and total ice volume $\sim 712 \mathrm{~km}^{3}$. The glacial lake inventory of the International Centre for Integrated Mountain Development (ICIMOD; Mool and others, 2010) indicates the study area contains 824 lakes, with total area $\sim 85 \mathrm{~km}^{2}$, of which 77 are identified as PDGLs, almost equal to the total number of PDGLs in India, Nepal and the Bhutan Himalaya (Ives and others, 2010). Moraine-dammed lakes in the Chinese Himalaya are unstable to global warming. At the same time, the ecology and socio-economic systems are highly vulnerable, and the capacity of residents to adapt to GLOF disasters in the study area is limited. More than 24 GLOF disasters have been reported in the Chinese Himalaya since 1935 (Fig. 1), and, with widespread glacier retreat and ongoing human activity in the high mountains, there are many potential threats resulting from moraine-dammed lake outbursts in the study area.

\section{DATA AND METHODS}

\subsection{Data}

The data for this study consist of Landsat imagery obtained on multiple dates in the 1990s and 2010s, topographic maps, Advanced Spaceborne Thermal Emission and Reflection Radiometer (ASTER) digital elevation models (DEMs) from 2009, and statistical data concerning the 


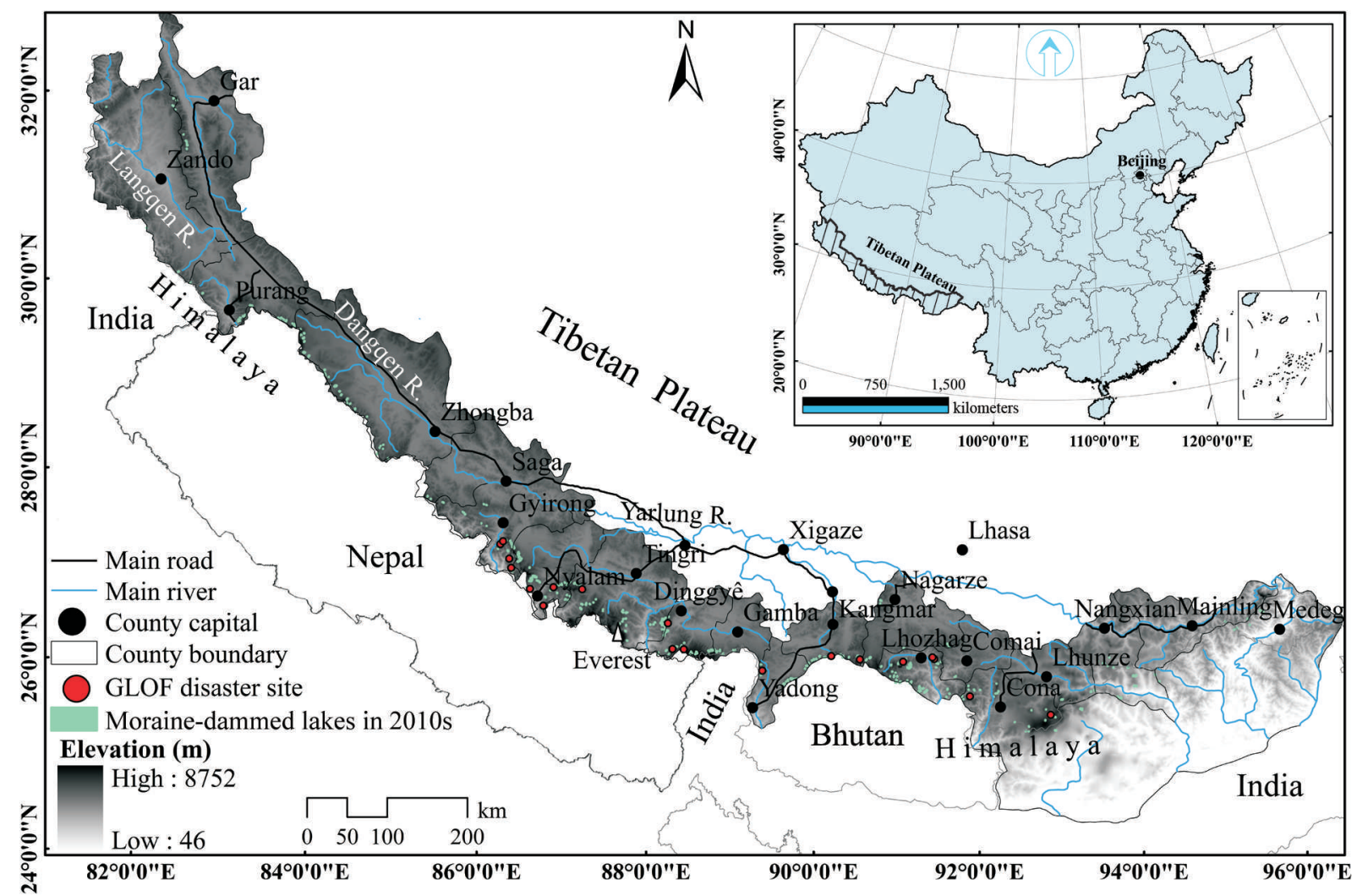

Fig. 1. Map of the Chinese Himalaya showing the major river basins, glacial lake distribution, recorded GLOF sites and 20 county boundaries.

socio-economic system in 2013. Image data are used to analyze the spatial and temporal variation of glacial lakes and identify their potential risk, whereas regional socioeconomic data are used to assess exposure, vulnerability and adaptation capacity in hazard-affected regions. To avoid cloud and snow cover during the monsoon and ensure minimal snow coverage, we selected 38 satellite images with $<5 \%$ cloud cover acquired between June and October in the 1990s and 2010s. The study area was observed with 38 Landsat Thematic Mapper (TM) and Enhanced TM Plus (ETM+) images with a spatial resolution of $30 \mathrm{~m}$ (http://glovis.usgs.gov).

Raw data for the socio-economic system were obtained from Statistical Yearbooks of the 20 counties and the Atlas of China Traffic (Starmap Publishing House, 2006). Given the large amount of data available, GIS is an essential tool to gather, store, handle, update, output and display spatial data. Most socio-economic statistical data are county-based, so our study is county-based rather than GLOF-catchmentbased. Different units were used to quantify the data. To compare them, the original data on evaluation factors need to be rendered dimensionless by transforming the range. Based on the method reported in previous studies (Zhao and others, 2006), we used normalization to standardize these data from various sources.

\subsection{Detection of moraine-dammed lakes}

Detection and monitoring of existing glacial lakes by remote-sensing methods are a research focus in various mountain regions (Frey and others, 2010). In our study, glacial lake boundaries, distributions and evolutions were investigated using detailed delineations and measurements of satellite-derived imagery. Images, when rectified, were further processed before interpretation, by comparing different band combinations. This showed that the standard falsecolor composite (FCC) images made from combining bands 4, 3 and 2 were most conducive for identifying glacial lake boundaries. When lakes were frozen and snow-covered, a visual inspection was needed to distinguish snow-covered glacial lakes, with the help of seven-, five- and two-band composites. Lakes are assumed to be areas where the slope is $<10 \%$ (Gardelle and others, 2011). All images then need to match with ERDAS software and images from two periods (1990s and 2010s), and require geographic registration to assure overlap with the ASTER global DEM (GDEM) of 2009 (http://datamirror.csdb.cn). The result of the image interpretation for a sub-scene of Nyalam county, central Himalaya, is shown in Figure 2.

Based on the image interpretation, all glacial lakes were delineated manually from digitized topographic maps and/ or FCC satellite images, pixel by pixel, in ArcGIS 9.3 with the help of Google Earth imagery. Finally, the vector layers of glacial lakes in the two periods were obtained, and attribute data - lake type, length, area and altitude - were established by eyewitness interpretation and geographic calculation. The measurement accuracy of glacial lake area from spatial data is limited by sensor resolution and manual digitizing. According to Wang and others (2011), the uncertainty in co-registration of multitemporal images can be calculated by

$$
\begin{gathered}
U_{\mathrm{L}}=\sqrt{\sum \lambda^{2}}+\sqrt{\sum \sigma^{2}} \\
U_{\mathrm{A}}=\frac{\left(2 U_{\mathrm{L}}\right)}{\sqrt{\sum \lambda^{2}}} \times \sum \lambda^{2} \times \sum \sigma^{2}
\end{gathered}
$$



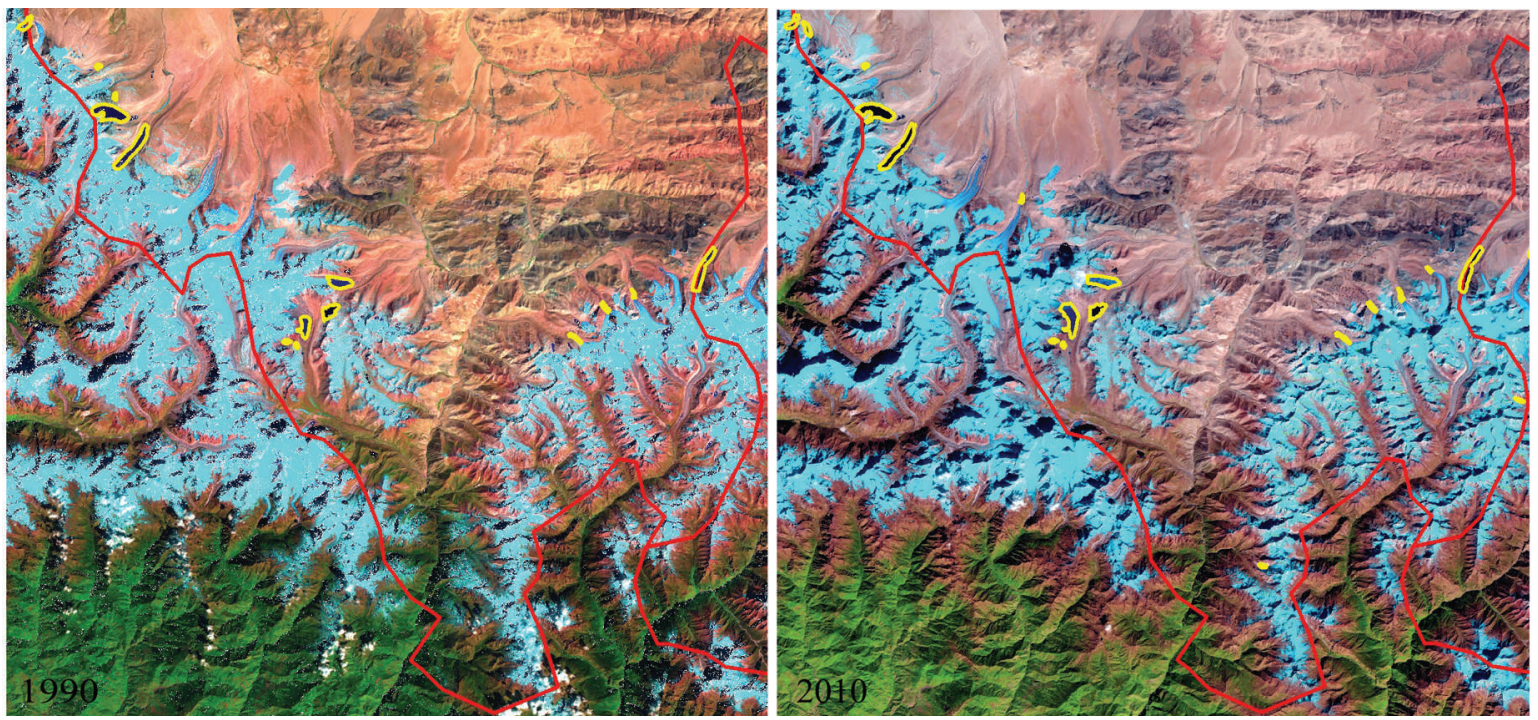

Fig. 2. Landsat ETM+ image and the result of moraine-dammed lakes (bounded by yellow) interpretation in Nyalam county, central Himalaya, in 1990 and 2010.

where $U_{\mathrm{L}}(\mathrm{m})$ is the linear uncertainty, $U_{\mathrm{A}}\left(\mathrm{m}^{2}\right)$ is the glacial lake's area uncertainty, $\lambda(\mathrm{m})$ is the original pixel resolution of each individual image and $\sigma(\mathrm{m})$ is the co-registration error of each individual image to topographic maps. Accordingly, the maximum error in co-registration $\left(U_{A}\right)$ for changes in glacial lakes from the 1990 s to the 2010 s was calculated as $\pm 0.017 \mathrm{~km}^{2}$.

\subsection{Identification of potentially dangerous glacial lakes}

At present, there are no unified criteria for identifying PDGLs. Generally, they are glacial lakes with a large probability of outburst that is likely to cause disaster downstream. Using multitemporal spaceborne stereo imagery, processes and records of past events, field investigations and other physical conditions, criteria include lake type, altitude, glacier area, snout steepness behind the lake, mean slope and height-to-width ratio of the moraine dam, presence of dead ice cores and permafrost lenses in the moraine, distance and slope between lake and glacier terminus, rate of lake formation and growth, climate and the situation down-valley including existence of settlements (Huggel and others, 2002, 2004; McKillop and Clague, 2007; Mool and others, 2010; Wang and Zhang, 2013).

Moraine-dammed lake area and its change, distance to the glacier terminus and existence of downstream settlements are most often employed by researchers as rough evaluation criteria to determine whether a lake is dangerous, because lake area affects the volume of stored water and the maximum outburst flood volume. Lake area variations reflect to some extent the state of their hydric balance. In the past 20 recorded GLOF disasters, 95\% of outburst lake areas exceeded $0.02 \mathrm{~km}^{2}$. Rapid changes in lake area will upset the hydric balance, thus promoting moraine-dammed lake outburst. The distance between lake and glacier terminus is a prerequisite for determining the amount of snow/ice/rock avalanches collapsed into the lakes from the glacier terminus, while the displacement waves from snow/ice/rock bodies that collapse into the lakes will further trigger an outburst flood (Awal and others, 2010; Schaub and others, 2013). Taking into account the availability of data obtained from remote sensing (not including fieldwork), we selected only moraine-dammed lake area $\left(>0.02 \mathrm{~km}^{2}\right)$, rate of lake area increase $(>20 \%)$, distance between lake and glacier snout $(<500 \mathrm{~m})$ and whether or not there were settlements downstream as the main candidate variables to evaluate whether a morainedammed lake is dangerous.

\subsection{Establishment of GLOF disaster risk assessment system}

Natural disaster risk assessment is the determination of a quantitative or qualitative value for risk related to a recognized threat from one or more natural events. A quantitative risk assessment should include two components: the probability of a natural hazard occurring, and the degree of damage expected to be caused by that natural hazard. Risk assessment is not only the basis of risk management, but is a systematic procedure for identifying and evaluating the likelihood of an undesirable outcome. Based on previous findings on natural disaster risk (Stallings, 1991; Bolin and Stanford, 1998; Wilhite, 2000; Wisner and others, 2004; Catani and others, 2005; Nadim and Kjekstad, 2009; Carey and others, 2012), GLOF disaster risk can be defined as a combination of the likelihood of a major glacial lake outburst event occurring (i.e. hazard), the degree of exposure to a GLOF hazard, the vulnerability (i.e. susceptibility) of exposed elements (people, property, etc.) that may be affected by a GLOF event, and adaptation capacity to prevent and respond to a GLOF disaster (i.e. management ability) (O'Keefe and others, 1976; Wisner and others, 2004). Unlike risk, a GLOF disaster is an actual occurrence, rather than a potential threat (Smith, 2001), so it may simply be defined as the realization of a glacial lake outburst hazard (a threatening event) affecting ecological, economic and social systems downstream.

Based on the above identification of GLOF disaster risk, a conceptual framework was established. The risk assessment conceptual framework contains three hierarchies: objective layer (A) (GLOF disaster risk), principal layer (B) (four main factors, $\mathrm{B}_{1}, \mathrm{~B}_{2}, \mathrm{~B}_{3}, \mathrm{~B}_{4}$ ) and index layer (C) (specific indicators, $C_{1}-C_{15}$ ) (Table 1).

Hazard $\left(B_{1}\right)$ reflects the possibility or likelihood of a moraine-dammed lake outburst and the severity of threats 
Table 1. GLOF disaster risk assessment indicator system and weights

\begin{tabular}{|c|c|c|c|c|}
\hline Objective layer (A) & Principal layer (B) & Index layer (C) & Unit & Weight \\
\hline GLOF disaster risk index ( $\mathrm{RI}_{\mathrm{GLOFD}}$ ) & Vulnerability $\left(\mathrm{B}_{3}\right)$ & $\begin{array}{c}\text { PDGLs number }\left(\mathrm{C}_{1}\right) \\
\text { PDGLs area }\left(\mathrm{C}_{2}\right) \\
\text { Area change of PDGLs }\left(\mathrm{C}_{3}\right) \\
\text { Population density }\left(\mathrm{C}_{4}\right) \\
\text { Livestock density }\left(\mathrm{C}_{5}\right) \\
\text { Cultivated area }\left(\mathrm{C}_{6}\right) \\
\text { Density of road network }\left(\mathrm{C}_{7}\right) \\
\text { Density of agricultural economy }\left(\mathrm{C}_{8}\right) \\
\text { Proportion of rural population }\left(\mathrm{C}_{9}\right) \\
\text { Percentage of small livestock }\left(\mathrm{C}_{10}\right) \\
\text { Road level }\left(\mathrm{C}_{11}\right) \\
\text { Building level }\left(\mathrm{C}_{12}\right) \\
\text { Regional GDP }\left(\mathrm{C}_{13}\right) \\
\text { Financial revenue share of GDP }\left(\mathrm{C}_{14}\right) \\
\text { Density of fixed assets investment }\left(\mathrm{C}_{15}\right)\end{array}$ & $\begin{array}{c}- \\
\mathrm{km}^{2} \\
\% \\
\text { person km-2 } \\
10^{4} \\
\mathrm{~km}^{2} \\
\mathrm{~km} \mathrm{~km}^{-2} \\
\text { Yuan km} \\
\% \\
\% \\
\% \\
\text { Yuan } 10^{4} \\
\text { Yuan } 10^{8} \\
\% \\
\text { Yuan } 10^{4} \mathrm{~km}^{-2}\end{array}$ & $\begin{array}{l}0.061 \\
0.186 \\
0.124 \\
0.053 \\
0.036 \\
0.037 \\
0.033 \\
0.040 \\
0.069 \\
0.038 \\
0.018 \\
0.021 \\
0.115 \\
0.092 \\
0.073\end{array}$ \\
\hline
\end{tabular}

and harm to downstream residents, property and ecosystems. When a PDGL coexists with vulnerable exposed elements, a serious GLOF disaster can result. Thus, identification of PDGLs is an important first step in hazard analysis of GLOF disaster risk. In this paper, PDGL number, area and expansion rate $\left(C_{1}-C_{3}\right)$ have been selected to describe the GLOF disaster risk.

Exposure $\left(\mathrm{B}_{2}\right)$ describes the spatial distribution and numbers of exposed elements and is expressed by the number and density of exposed elements. On the whole, the more (fewer) people and the higher (lower) the value of property exposed to a GLOF, the greater (smaller) are potential losses. The study selected population, livestock, cultivated land, road network and density of the agricultural economy $\left(C_{4}-C_{8}\right)$ as specific indicators to assess the degree of exposure to GLOFs: 'population' and 'livestock' density were chosen to describe the life exposure, while 'cultivated land' and 'density of road network' were selected to describe the socio-economic exposure.

Vulnerability $\left(\mathrm{B}_{3}\right)$ indicates the susceptibility of exposed elements and the extent of damage and loss in terms of population, property and other elements affected by GLOFs. Higher vulnerability will result in greater disaster losses. GLOFs often endanger farmers, herdsmen, livestock, loads, buildings and other exposed elements in mountainous areas. The percentage of rural population, small livestock and road and building level $\left(\mathrm{C}_{9}-\mathrm{C}_{12}\right)$ are particularly vulnerable to GLOFs, and are therefore selected to describe life and socioeconomic vulnerability.

Adaptation capacity $\left(\mathrm{B}_{4}\right)$ is also called risk management ability. It reflects early monitoring, warning and forecasting levels of moraine-dammed lake outburst and defense capabilities to reduce lake water level, regional exposure and vulnerability to an outburst. Regional GDP and financial revenue share of GDP $\left(\mathrm{C}_{13}-\mathrm{C}_{14}\right)$ are selected to describe the economic capacity of regional and local government to prevent GLOF disasters, while the density of fixed assets investment $\left(C_{15}\right)$ is selected to indicate the current status of regional project measures for preventing and mitigating GLOF disasters.

Of the specific indicators, road level $\left(C_{11}\right)$ reflects the proportion of provincial highways in the total road mileage, while, due to lack of data, building level $\left(\mathrm{C}_{12}\right)$ is replaced by net income of regional farmers and herdsmen.

\subsection{Determining the index weight}

We determined the index weight by the analytic hierarchy process (AHP), originally developed by Saaty (1977). AHP is a decision analysis method which combines quantitative and qualitative criteria in decision problems. An 'expert questionnaire' was used to obtain weighting values for complex factors. This process comprised five basic steps: (1) questionnaire design, (2) calculation of a pairwise comparison matrix, (3) estimation of relative weighting values (a scale from 1 (two components contribute equally to GLOF disaster risk) to 9 (one component predominates completely over the other in causing GLOF disaster occurrence) was used to compare pairs of components), (4) examination of consistency and (5) aggregation of the weights to determine a ranking of decision alternatives (Davidson and Lambert, 2001; Zhang, 2004; Wu and Chen, 2009; Wang and Zhao, 2011).

The weight values assessed by AHP and used for the GLOF disaster risk are shown in Table 1. The weight values of the hazard, exposure, vulnerability and adaptation capacity factors are $0.37,0.20,0.15$ and 0.28 , respectively. The main (top six) indicators of index layer are arranged as follows: PDGL area, rate of PDGL area change, regional GDP, revenue share of GDP, density of fixed assets investment and proportion of rural population. The contribution degree of the top six factors was up to $66 \%$. PDGL area determines water volume, the magnitude of PDGL outburst and its disaster degree. Rapid expansion of larger PDGLs is highly correlated with outburst probability. Regional GDP, revenue share of GDP and fixed assets investment can reduce or prevent GLOF disaster risk or damage, and are equally important. Population density is the most important factor in exposed elements, directly determining the degree of GLOF disaster risk to human safety.

\subsection{GLOF disaster risk assessment model}

The reduction of exposure and vulnerability of exposed elements can lessen the likelihood of GLOF disaster occurrence downstream, and strong adaptation capacities will prevent or reduce GLOF disaster risk. GLOF disaster risk is generally positively correlated with hazard, exposure and vulnerability, while it is negatively correlated with adaptation capacity. Thus, a basis for risk assessment of GLOF disaster is to include hazard and exposure, as well as vulnerability and adaptation capacity, in the assessment process. 

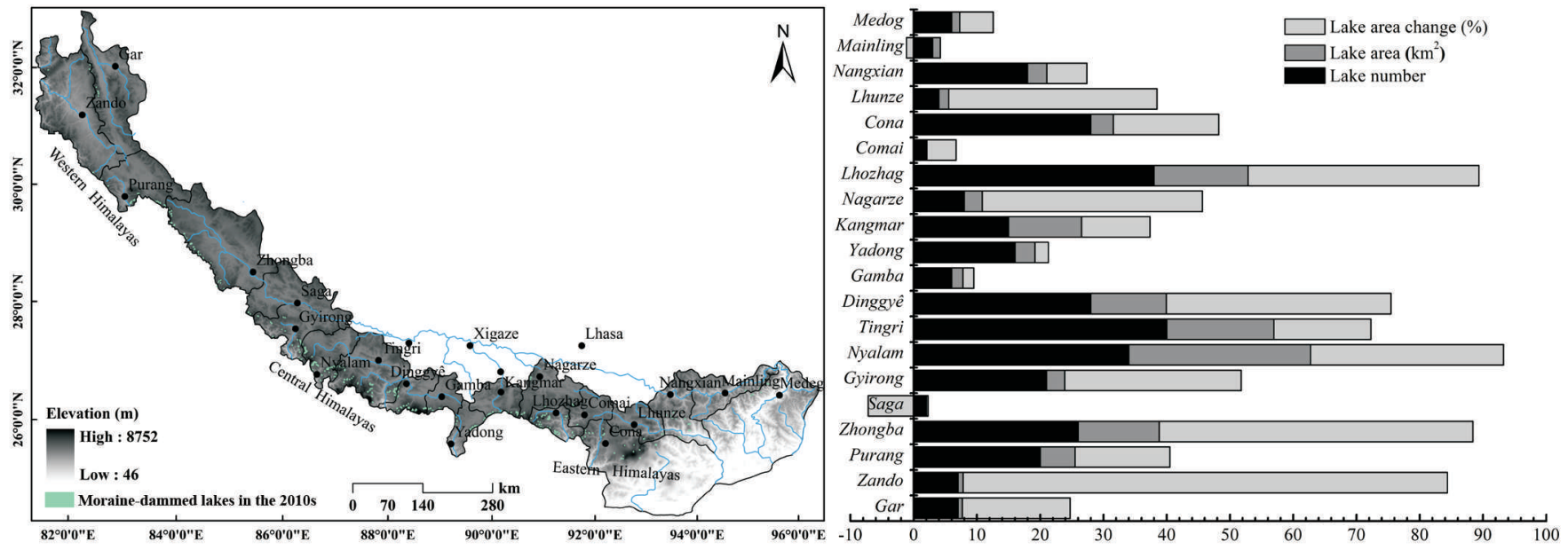

Fig. 3. Distribution and evolution of moraine-dammed lakes in the Chinese Himalaya.

Taking into account the above risk analysis and past related research (Zhang and others, 2009; Liu and others, 2011), we developed the following equations to determine the degree of risk of GLOF disaster and the four main factors by integrating the assessment method of other natural disaster risks:

$$
\begin{gathered}
\mathrm{RI}_{\mathrm{GLOFD}}=(H E V) / A \\
H(E, V, A)=\sum_{i}^{m} w_{i} x_{i j}^{\prime} \\
x_{i j}^{\prime}=10\left(x_{i j} / x_{\max }\right)
\end{gathered}
$$

where $\mathrm{RI}_{\mathrm{GLOFD}}$ (risk index of GLOF disaster) indicates the degree of GLOF disaster risk (generally, the higher the value, the greater the degree of GLOF disaster risk) and $H, E, V$ and $A$ are the hazard, exposure, vulnerability and adaptation capability factors, respectively $(A>0) . m$ is the number of indicators reflecting hazard, exposure, vulnerability and adaptation capability factors. $x_{i j}, x_{i j}^{\prime}$ refer to the unscaled and scaled values of the ith indicator of index layer $C$ in the ith county $\left(0<x^{\prime}{ }_{i j}<10\right)$. $w_{i j}$ is the weight of the ith indicator of index layer $C$ in the $j$ th county relative to objective layer $A$ $\left(0<w_{i}<1\right)$ (Table 1$)$ and is obtained by AHP. $x_{\max }$ is the maximal value of the indicators $x_{i j}$. A large (small) value of $x_{i j}^{\prime}$ means that this factor has a greater (lesser) impact on GLOF disaster risk.

The degrees of GLOF disaster risk can be compared using $\mathrm{RI}_{\mathrm{GLOFD}}$. It is found that when $H E V=0, \mathrm{RI}_{\mathrm{GLOFD}}=0$. With adaptation capability, $A \neq 0$ decreases and the $\mathrm{RI}_{\mathrm{GLOFD}}$ value increases. When the hazard, exposure and vulnerability are reduced and management ability increases, $\mathrm{RI}_{\text {GLOFD }}$ decreases.

\section{RESULTS AND ANALYSIS}

\subsection{Distribution and evolution of moraine-dammed lakes}

In the Chinese Himalaya, 329 moraine-dammed lakes $\left(>0.02 \mathrm{~km}^{2}\right)$ with a total area of $125.43 \mathrm{~km}^{2}$ were detected from remotely sensed data in the 2010s. The areas of moraine-dammed lakes range from $0.02 \mathrm{~km}^{2}$ to $5.80 \mathrm{~km}^{2}$, at altitudes between 3500 and $5636 \mathrm{~m}$ (Fig. 3). As shown in
Figure 3, 329 lakes were distributed through the 20 counties. Of these, Tingri has the most lakes $(40 ; 12.16 \%$ of the total number in the study area), and Nyalam has the largest lake area $\left(28.74 \mathrm{~km}^{2} ; 22.91 \%\right.$ of the total moraine-dammed lake area). Lhozhag has 38 lakes with a total area of $14.85 \mathrm{~km}^{2}$. Tingri, Nyalam and Lhozhag together account for $34.04 \%$ of the total number of lakes and $48.25 \%$ of the total lake area. Lake area is relatively small $\left(<1 \mathrm{~km}^{2}\right)$ in other counties.

In the past 20 years, the total area of moraine-dammed lakes has expanded by $25.11 \%$, from $100.26 \mathrm{~km}^{2}$ in the $1990 \mathrm{~s}$ to $125.43 \mathrm{~km}^{2}$ in the $2010 \mathrm{~s}$. The magnitude of lake area increase between the 1990s and 2010s has been largest in Zhongba county $(49.60 \%)$, followed by Lhozhag (36.50\%), Dinggyê (35.51\%), Nagarze (34.81\%), Lunze $(32.89 \%)$ and Nyalam $(30.50 \%)$. Lake area in Saga and Mainling decreased by $7.19 \%$ and $1.15 \%$, respectively. In other counties, the magnitude of lake area change was $1-28 \%$. Lake area variations in the study area exhibit regional differences (Fig. 3). It is noteworthy that the area of 27 moraine-dammed lakes in the study area decreased by $>15 \%$, which means that these lakes have likely burst without detection.

\subsection{Distribution and evolution of PDGLs}

The results show that 116 moraine-dammed lakes with a total area of $49.49 \mathrm{~km}^{2}$ in the $2010 \mathrm{~s}$ are identified as PDGLs; all PDGLs with an area $\geq 0.02 \mathrm{~km}^{2}$ are $<500 \mathrm{~m}$ from the glacier terminus, and growth rates of all PDGLs have exceeded $20 \%$ in the past two decades. PDGLs comprise $35.26 \%$ and $39.46 \%$ of the total number and area, respectively, of lakes in the study area. From the 1990s to the 2010s, the total area of PDGLs increased significantly by $66.87 \%$, significantly higher than the increase rate of nonPDGLs (7.57\%) in the study area in the same period. Table 2 lists 31 PDGLs with an area $>0.5 \mathrm{~km}^{2}$ and a rate of lake area increase $>50 \%$.

PDGLs are distributed mainly in the mid-eastern Himalaya, and are rare in the western region (Fig. 3; Table 3). Lhozhag has the most PDGLs (19), followed by Tingri (14), Dinggyê (12) and Cona (11). PDGLs in these four counties account for about half of the total number of PDGLs in the study area. Most PDGLs are in contact with parent glaciers and are considered large enough to cause damage downstream if they outburst (Tables 2 and 3). 
Table 2. Distribution and evolution of 31 PDGLs with area $>0.5 \mathrm{~km}^{2}$ in the 2010 s and area increase by $>20 \%$ in the study area in the past 20 years

\begin{tabular}{|c|c|c|c|c|c|c|c|}
\hline \multirow[t]{3}{*}{ Lake } & \multirow[t]{3}{*}{ Location } & \multirow[t]{2}{*}{ Long. } & \multirow[t]{2}{*}{ Lat. } & \multicolumn{2}{|l|}{ Area } & \multirow[t]{2}{*}{$\begin{array}{l}\text { Area change } \\
1990 s-2010 s\end{array}$} & \multirow[t]{3}{*}{$\begin{array}{c}\text { Distance to } \\
\text { glacier in } 2010 \mathrm{~s}\end{array}$} \\
\hline & & & & $1990 \mathrm{~s}$ & 2010s & & \\
\hline & & $\circ$ & $\circ$ & $\mathrm{km}^{2}$ & $\mathrm{~km}^{2}$ & $\%$ & \\
\hline Kangbuco & Nagarze & 90.22 & 28.93 & 0.346 & 0.515 & 48.73 & 260 \\
\hline \multirow[t]{5}{*}{ Kenlongco } & Burang & 81.93 & 30.39 & 0.352 & 0.568 & 61.48 & 0 \\
\hline & Lhunze & 93.09 & 28.34 & 0.343 & 0.573 & 66.83 & 0 \\
\hline & Burang & 82.05 & 30.36 & 0.465 & 0.576 & 23.90 & 0 \\
\hline & Yadong & 89.27 & 27.85 & 0.436 & 0.579 & 32.95 & 0 \\
\hline & Tingri & 86.53 & 28.19 & 0.483 & 0.589 & 21.99 & 0 \\
\hline Paquco & Nyalam & 86.16 & 28.30 & 0.403 & 0.605 & 50.28 & 250 \\
\hline Wenjiafu & Lhozhag & 90.57 & 28.12 & 0.280 & 0.616 & 120.41 & 0 \\
\hline Yayouco & Lhozhag & 91.07 & 28.35 & 0.216 & 0.775 & 259.11 & 0 \\
\hline \multirow[t]{2}{*}{ Chazhuco } & Zhongba & 82.97 & 29.74 & 0.498 & 0.792 & 59.24 & 0 \\
\hline & Tingri & 86.53 & 28.13 & 0.680 & 0.818 & 20.24 & 0 \\
\hline Yaquco & Tingri & 87.05 & 28.07 & 0.620 & 0.837 & 34.95 & 0 \\
\hline Pidaco & Dinggyê & 88.07 & 27.93 & 0.502 & 0.859 & 71.35 & 0 \\
\hline Jimico & Dinggyê & 87.93 & 27.95 & 0.660 & 0.874 & 32.32 & 0 \\
\hline Duoyico & Tingri & 86.38 & 28.39 & 0.376 & 0.878 & 133.42 & 0 \\
\hline Xiaco & Tingri & 87.59 & 28.23 & 0.566 & 0.953 & 68.44 & 0 \\
\hline Guqingco & Nyalam & 85.60 & 28.56 & 0.274 & 1.038 & 278.88 & 0 \\
\hline Jilaipuco & Dinggyê & 87.77 & 27.93 & 0.711 & 1.051 & 47.85 & 0 \\
\hline Tajuco & Tingri & 87.56 & 28.18 & 0.654 & 1.143 & 74.83 & 0 \\
\hline \multirow[t]{2}{*}{ Zhixico } & Dinggyê & 88.00 & 27.93 & 0.919 & 1.193 & 29.81 & 0 \\
\hline & Nagarze & 90.23 & 28.28 & 1.004 & 1.300 & 29.41 & 0 \\
\hline Jiemayangzong & Zhongba & 82.21 & 30.26 & 0.783 & 1.350 & 72.42 & 0 \\
\hline Longbasaba & Dinggyê & 88.08 & 27.95 & 0.554 & 1.360 & 145.41 & 0 \\
\hline \multirow[t]{2}{*}{ Bailangco } & Lhozhag & 90.79 & 28.09 & 1.084 & 1.938 & 78.75 & 0 \\
\hline & Zhongba & 82.78 & 29.84 & 1.828 & 2.949 & 61.36 & 0 \\
\hline Gangxico & Nyalam & 85.87 & 28.36 & 2.782 & 4.719 & 69.65 & 260 \\
\hline
\end{tabular}

\subsection{Assessment and regionalization of GLOF disaster risk factor}

When analyzing GLOF disaster risks, the formation mechanism of the risks must be followed. The four main factors that form GLOF disaster risk should be analyzed separately. We calculated hazard, exposure, vulnerability degree and adaptation capability, using Eqn (4). Regionalization maps are drawn by the GIS equal interval classification method (Fig. 4).

The regionalization results show that hazard levels are 'very low' or 'low' in Saga, Gamba, Mainling, Medeg, Comai, Yadong, Kangmar and Nangxian. The regions with moderate or high GLOF disaster hazard levels are located in Gar, Purang, Gyirong, Ngarze, Cona, Lhunze and Zando, while the very high-hazard zones are concentrated in Zhongba, Nyalam, Tingri, Dinggyê and Lhozhag. Overall, the larger PDGL areas have a higher hazard level. For example, PDGL areas in Zhongba, Nyalam, Tingri, Dinggyê and Lhozhag were 8.53, 7.97, 6.79, 6.85 and $7.26 \mathrm{~km}^{2}$ respectively, in the 2010s, with PDGL area increasing by $>60 \%$ everywhere except for Tingri (47.26\%) (Fig. 4a; Table 3). In contrast, Zando has the fewest lakes (five) and the smallest PDGL area, but the fastest-growing lake area $(227 \%)$. Thus, Zando has a higher GLOF disaster hazard level (Fig. 4a).
Figure $4 b$ shows the spatial distribution of exposure levels across the study area. Overall, the exposure level of GLOFs increases from northwest to southeast, except for Gar. Lhunze, Mainling, Nangxian, Yadong and Gar have high and very high degrees of exposure. Lhunze has the highest density of population and livestock (8.24 persons km ${ }^{-2}$ and 54.84 sheep units $\mathrm{km}^{-2}$ ). Other counties have middle, low or very low degrees of exposure, especially Zando, Purang, Saga, Dinggyê, Gamba and Kangmar. Of these counties, Zando and Purang have the lowest density of population and livestock $\left(<1\right.$ person $\mathrm{km}^{-2}$ and 10 sheep units $\mathrm{km}^{-2}$ ).

Figure 4c shows that GLOF disaster vulnerability level is higher in the northwest Himalaya than the southeast, with Purang, Zhongba, Nyalam and Kangmar having very high, and Gar, Sag, Tingri and Gamba having high vulnerability levels. Tingri and Zhongba have the highest proportion of non-agricultural population $(95.41 \%$ and $94.86 \%$, respectively) and the smallest proportion of livestock $(26.63 \%$ and $53.65 \%$, respectively), while Dinggyê, Gyirong, Zando and Medeg have the lowest level of road and housing construction. A higher proportion of non-agricultural population, smaller proportion of livestock and a higher construction level (e.g. roads and housing) greatly reduces the vulnerability of exposed elements and enhances their resilience. 

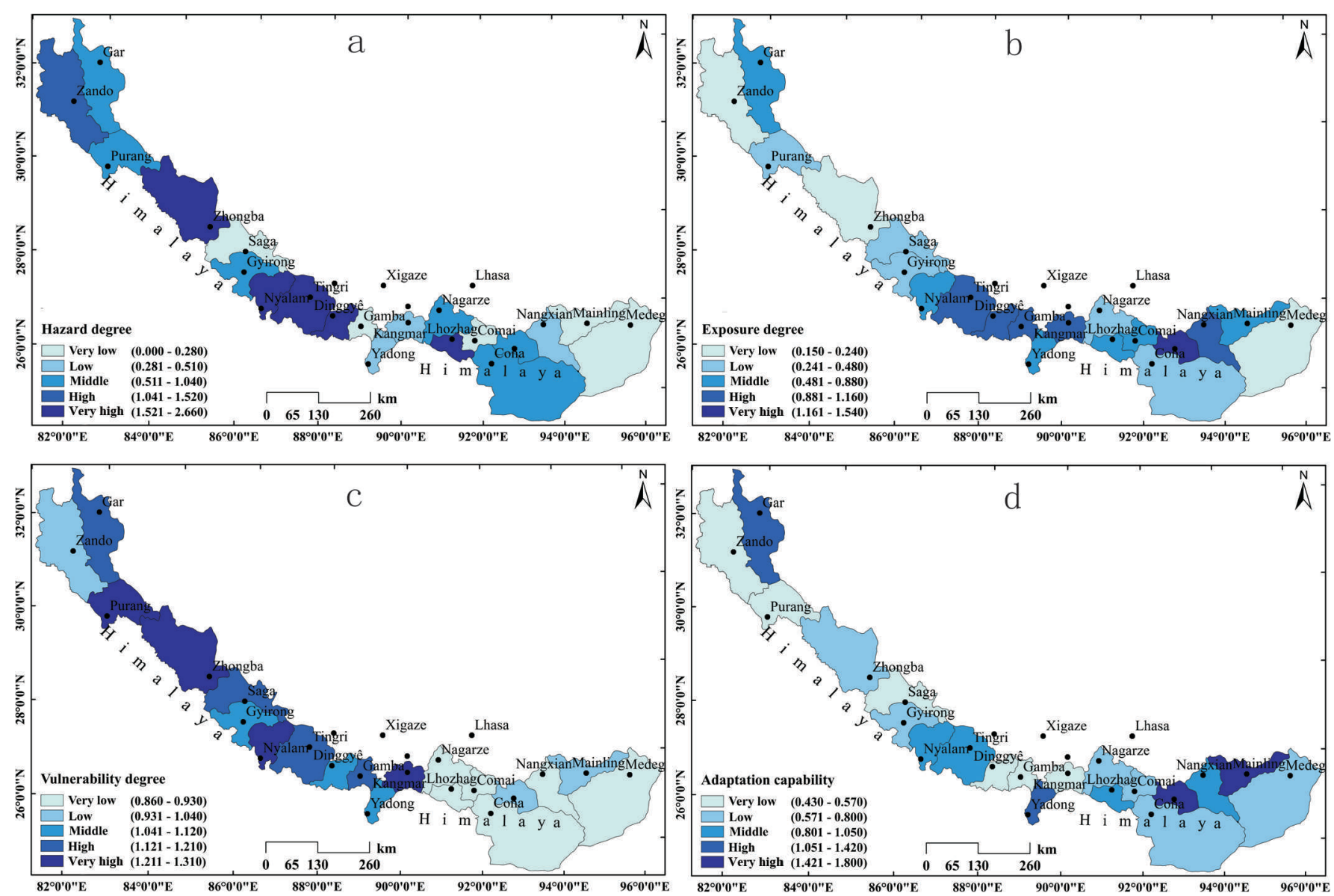

Fig. 4. Map of hazard degree (a), exposure degree (b), vulnerability degree (c) and adaptation capability degree (d) for 20 counties in the study area.

Table 3. Distribution and variation of PDGLs in 20 counties in the study area

\begin{tabular}{|c|c|c|c|c|}
\hline \multirow[t]{3}{*}{ County } & \multirow[t]{3}{*}{ PDGLs in 2010s } & \multicolumn{3}{|c|}{ Lake area } \\
\hline & & $1990 \mathrm{~s}$ & 2010s & Change rate \\
\hline & & $\mathrm{km}^{2}$ & $\mathrm{~km}^{2}$ & $\%$ \\
\hline Gar & 3 & 0.110 & 0.22 & 107.64 \\
\hline Zando & 5 & 0.160 & 0.53 & 226.63 \\
\hline Burang & 9 & 1.390 & 2.13 & 52.67 \\
\hline Zhongba & 10 & 4.600 & 8.53 & 85.56 \\
\hline Saga & 1 & 0.120 & 0.17 & 35.35 \\
\hline Gyirong & 5 & 0.520 & 1.09 & 108.36 \\
\hline Nyalam & 9 & 4.600 & 7.97 & 73.28 \\
\hline Tingri & 14 & 4.610 & 6.79 & 47.26 \\
\hline Dinggyê & 12 & 4.210 & 6.85 & 62.62 \\
\hline Gamba & 0 & 0.000 & 0.00 & 0.00 \\
\hline Yadong & 3 & 0.600 & 0.81 & 34.99 \\
\hline Kangmar & 3 & 1.110 & 1.89 & 0.712 \\
\hline Nagarze & 4 & 1.830 & 2.45 & 34.04 \\
\hline Lhozhag & 19 & 3.890 & 7.26 & 86.12 \\
\hline Comai & 0 & 0.000 & 0.00 & 0.00 \\
\hline Cona & 11 & 0.800 & 1.08 & 34.87 \\
\hline Lhunze & 3 & 0.510 & 0.92 & 80.04 \\
\hline Nangxian & 3 & 0.270 & 0.37 & 39.64 \\
\hline Mainling & 1 & 0.190 & 0.26 & 35.50 \\
\hline Medog & 1 & 0.140 & 0.18 & 26.19 \\
\hline Total & 116 & 29.66 & 49.49 & 66.87 \\
\hline
\end{tabular}

The economic base determines the capacity for disaster prevention and mitigation. In 2012, GDP and financial revenue of the 20 counties was Yuan 61.867 billion and Yuan 3.06 billion, accounting for $8.82 \%$ and $9.95 \%$, respectively, of the Tibet Autonomous Region totals. The GDP of Gamba, Comai, Gar, Purang and Zando counties was Yuan $<200$ million. The area density of fixed asset investment in Purang, Zando and Zhongba counties is Yuan $<10000 \mathrm{~km}^{-2}$. Figure 4d indicates very low GLOF disaster adaptation capability levels in Zando, Purang, Sag, Dinggyê, Gamba and Kangmar, and low levels in Zhongba, Gyirong, Ngarze, Comai, Cona and Medeg. The regions with moderate and high levels of adaptation capability are located in Nyalam, Tingri, Lhozhag, Nangxian, Gar and Yadong, whereas the very high adaptation capability zones are concentrated in Lhozhag and Mailing, eastern Himalaya.

\subsection{Assessment and regionalization of overall GLOF disaster risk}

After analyzing the four main factors forming GLOF disaster risk, we assessed the overall degree of GLOF disaster risk for the 20 counties. The spatial distribution of GLOF disaster risk degree in the study area is shown in Figure 5. The results show that the maximum, mean and minimum regional $\mathrm{RI}_{\mathrm{GLOFD}}$ are 4.81, 0.95 and 0, respectively. Based on the above results, the $\mathrm{RI}_{\mathrm{GLOFD}}$ values were used as the criteria for zoning the GLOF disaster risk degree in the study area. According to the $\mathrm{RI}_{\mathrm{GLOFD}}$ value and the historical data of GLOF disasters, risk was classified into the following five grades: very low risk $\left(\mathrm{RI}_{\mathrm{GLOFD}}<0.120\right)$, low 


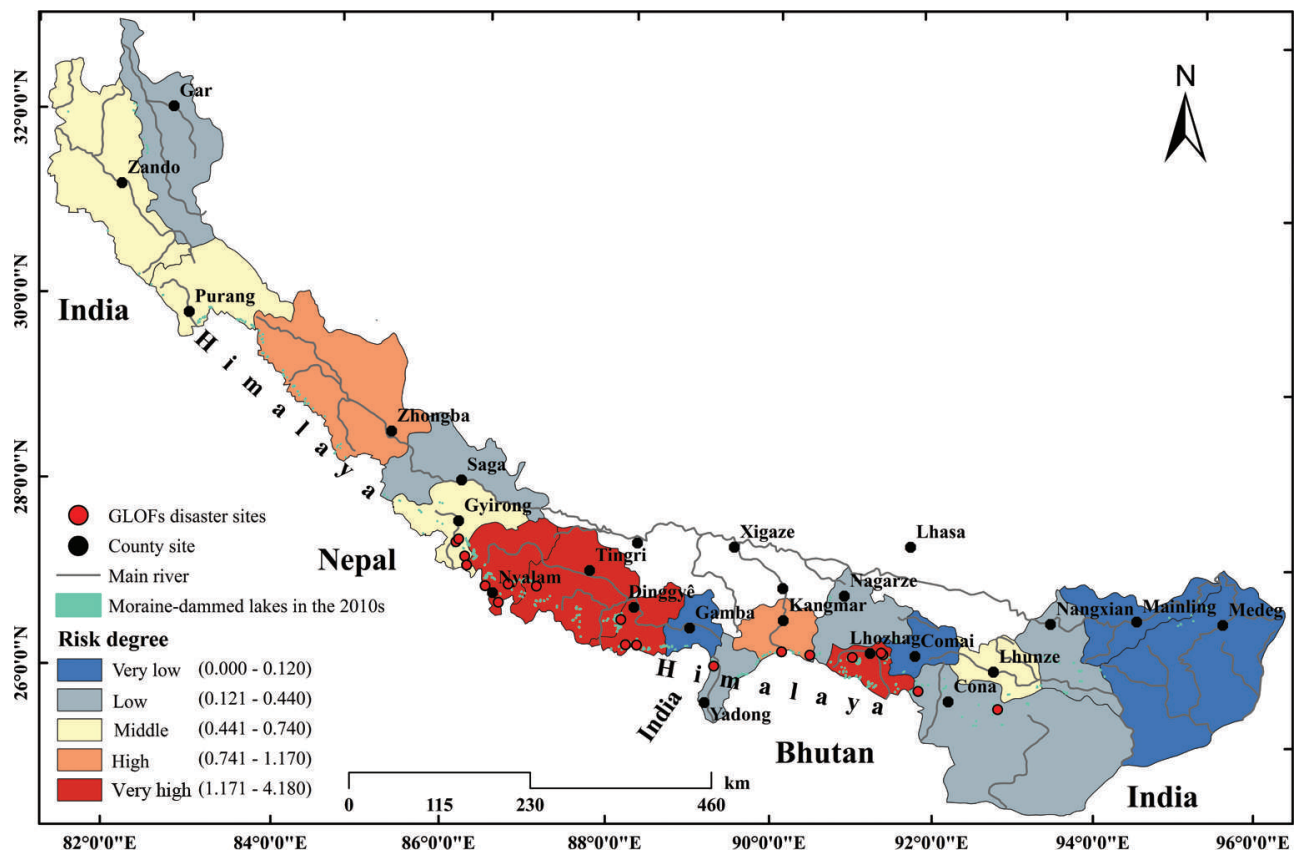

Fig. 5. Map of risk degree of GLOF disasters in 20 counties in the Chinese Himalaya.

risk $\left(0.121 \pm \mathrm{RI}_{\mathrm{GLOFD}}<0.440\right)$, medium risk $(0.441 \pm \mathrm{RI}$ GLOFD $<0.740)$, high risk $\left(0.741 \pm \mathrm{RI}_{\mathrm{GLOFD}}<1.170\right)$ and very high risk $\left(\mathrm{RI}_{\mathrm{GLOFD}} \geq 1.171\right)$.

Figure 5 shows that Nyalam, Tingri, Dinggyê and Lhozhag are in the very high-risk zone. Dinggyê has the highest $\mathrm{RI}_{\mathrm{GLOFD}}$ (4.81) with very high hazard degree and very low adaptation capacity. It is worth noting that at least 14 GLOF disasters have occurred in very high-risk zones since 1935 . High-risk zones account for $58.33 \%$ of GLOF disasters in the study area, most of these caused by outbursts from Cirenmaco lake (1981) and Jialongco lake (2002) in Nyalam, and Yindaco lake and Jinco lake (1982) in Dinggyê. Kangmar and Zhongba are in high-risk zones, while other counties are in middle-, low- and very low-risk zones. The high- and very high-risk zones are mainly in the central and central-eastern Himalaya, while low- and very low-risk zones are in the far eastern Himalaya.

The GLOF disaster risk assessment results are consistent with the distribution of historic disaster sites across the Chinese Himalaya. Accordingly, the research results can provide practical guidelines and the basis for policy decisions on regional GLOF disaster prevention and mitigation. Specifically, local governments should prioritize very high-risk zones in the process of GLOF disaster prevention and mitigation, and should take medium- and high-risk zones as key areas for monitoring morainedammed lake change.

\section{CONCLUSIONS AND DISCUSSION}

The purpose of risk assessment is to assist the management of risk, scientifically and rationally, to safeguard against loss (e.g. damage to property, loss of life). Management is indispensable in mitigating and adapting to risk in order to safeguard people and assets including property. Risk management methods can be divided into three categories: risk control, risk transfer and risk self-retention. Risk control involves reducing the likelihood of a natural event occurring, or reducing the severity of loss from the event. Risk transfer is the removal of exposed elements and at-risk structures to a secure zone, or the transfer of risk to a third party through insurance or contract. Risk self-retention involves accepting the loss from a risk when it does occur, in which case acceptable risk is a risk that is understood and tolerated, usually because the cost or difficulty of implementing an effective countermeasure for the associated vulnerability exceeds the expectation of loss. Of the three management methods, risk control should be the priority approach. Risk control measures to alleviate GLOF disasters involve reducing lake water level by using structural measures (e.g. pumping lake water, tunneling through the moraine dam), reinforcing moraine dams, bridges, riverbanks and other infrastructure, installing drainage grooves, reducing vulnerability of exposed elements (e.g. the rural population, small livestock) and improving their adaptation capacity (e.g. regional GDP, financial revenue share of GDP and density of fixed assets investment).

Risk transfer suggests the removal of exposed elements and structures (e.g. population, livestock, cultivated area, road and housing construction) to a secure area. Alternatively, it can be the transfer of risk to another entity through insurance or contractor. For GLOF disasters with acceptable risk, risk self-retention measures may be preferred, and these are often within the capabilities of communities with relatively weak economies.

We have analyzed the spatial distribution and evolution of moraine-dammed lakes and PDGLs in the Chinese Himalaya and assessed a methodology and model of county-based GLOF disaster risk through integrative multiattribute analysis of GLOF disaster hazard, exposure, vulnerability and adaptation capacity. In the study area, 116 moraine-dammed lakes with a total area of $49.49 \mathrm{~km}^{2}$ in the 2010s are identified as PDGLs, most in the central Himalaya. From the 1990s to the 2010s, the total PDGL area increased by $66.87 \%$. The same period also saw an increase, though less significant $(7.57 \%)$, in the area of non-dangerous glacial lakes. The risk assessment results indicate that the very high- and high-risk GLOF disaster 
zones are mainly concentrated in Nyalam, Tingri, Dinggyê, Lhozhag, Kangmar and Zhongba in the mid-eastern Himalaya, consistent with the PDGL distribution.

Very-high-risk and high-risk GLOF disaster zones need to be investigated. The disaster potential can be reduced, and even eliminated, using risk control and transfer methods. First, very-high- and high-risk glacial lakes need to be identified, and realistic impact maps need to be constructed using GLOF modeling techniques (e.g. BREACH, DAMBRK, FLDWAV (e.g. Fread, 1984a,b, 1988) and RAMMS (e.g. Bartelt and others, 2014)).

To reduce lake levels, structural and engineering measures are required, according to the degree of GLOF impact, in order to decrease pressure on moraine dams and reduce water volume in case of an outburst. Primary techniques and measures for this include controlled breaching, construction of outlet control structures, pumping or siphoning water from the lake, and tunneling the moraine dam.

Local residents and assets in very-high-risk and high-risk zones should be moved to more secure areas. These measures cannot, however, be heavily relied upon for the future of reducing GLOF disaster risk. Preferred measures should aim at improving land use, transportation and town planning in very high-risk zones, taking the exposed elements away from threats of high-risk PDGLs.

In middle- and low-risk zones, automated or manual monitoring and early-warning systems need to be set up in GLOF-prone districts. To provide basic data, the main necessity is to have models of realistic scenarios of longterm PDGL and glacier evolution (Linsbauer and others, 2012, 2013). At the same time, stabilization and heightening of moraine walls, stabilization of hazard-prone slopes and riverbanks and improvements to the structural integrity of drainage systems need to be carried out. There is also a need for GLOF risk mitigation training and education through schools and other public educational and civil institutions, paying close attention to local residents' self-understanding and self-monitoring of high-risk PDGLs in GLOF-prone districts. In low-risk zones, risk management must focus on strengthening land-use planning. It is worth emphasizing that GLOF disaster impacts on downstream areas will gradually be reduced or eliminated by enhancing disaster prevention and mitigation capabilities.

Glacier ice thicknesses and widths are expected to continue to reduce across the Himalaya over the next several decades, and surface slopes are expected to increase, leading to new and further expansion of existing glacial lakes, with the inherent increased risk of GLOFs and, thus, potential threat to the population and infrastructure in the valleys below. Through this study we can develop a comprehensive understanding of regional GLOF disaster risk, and gain insight into the main factors contributing to it, in 20 counties in the Chinese Himalaya. These findings can provide a scientific basis for guiding actions on GLOF disaster prevention and mitigation in the future. However, limitations of the available data mean that some important factors influencing GLOF disaster risk were beyond the capacity of the present study. These factors include the conditions of associated glaciers, moraine dams, surrounding environment, situations down-valley, and specific exposed elements (population, houses, land, road, infrastructure, etc.) that are potentially directly affected, existence of disaster risk funds and insurance and residents' risk awareness levels. To improve the accuracy of GLOF disaster risk assessment, we must strengthen monitoring and field research work for other critical factors. In detail we need to consider key valleys as basin units in which to simulate moraine dam failure of the high-priority lakes, evaluate potential GLOF disaster impacts in the valleys using appropriate models, and strive to make assessment results more objective and factual than in the present study.

\section{ACKNOWLEDGEMENTS}

This work was funded by the National Basic Research Program of China (2013CBA01808), the National Social Science Foundation of China (grant No.14BGL137), the Innovative Research Group National Natural Science Foundation of China (grant No. 41121001), the China Postdoctoral Science Foundation (2013M530436) and the Foundation for Excellent Youth Scholars of the Cold and Arid Regions Environmental and Engineering Research Institute, Chinese Academy of Sciences (Y451141001). We thank Wilfried Haeberli and anonymous reviewers for helpful comments and suggestions, which considerably improved the final manuscript.

\section{REFERENCES}

Ashraf A, Naz R and Roohi R (2012) Glacial lake outburst flood hazards in Hindukush, Karakoram and Himalayan Ranges of Pakistan: implications and risk analysis. Geomat. Natur. Hazards Risk, 3(2), 113-132 (doi: 10.1080/19475705.2011.615344)

Awal R, Nakagawa H, Fujita M, Kaiwake K, Baba Y and Zhang H (2010) Experimental study on glacial lake outburst floods due to waves overtopping and erosion of moraine dam. Ann. Disaster Prev. Res. Inst., 53(B), 583-594

Bajracharya SR, Mool PK and Shrestha B (2007) Impact of climate change on Himalayan glaciers and glacial lakes: case studies on GLOF and associated hazards in Nepal and Bhutan. (ICIMOD Publication 169) International Centre for Integrated Mountain Development and United Nations Environment Programme Regional Office, Asia and the Pacific, Kathmandu

Bartelt P, Buser O, Bühler Y, Dreier L and Christen M (2014) Numerical simulation of snow avalanches: modelling dilatative processes with cohesion in rapid granular shear flows. In Proceedings of the 8th European Conference on Numerical Methods in Geotechnical Engineering, NUMGE 2014, Vol. 1. CRC Press, Delft, 327-332

Benn DI and 9 others (2012) Response of debris-covered glaciers in the Mount Everest region to recent warming, and implications for outburst flood hazards. Earth-Sci. Rev., 114(1-2), 156-174 (doi: 10.1016/j.earscirev.2012.03.008)

Bolin RC and Stanford L (1998) The Northridge earthquake: vulnerability and disaster. Routledge, London

Carey M (2005) Living and dying with glaciers: people's historical vulnerability to avalanches and outburst floods in Peru. Global Planet. Change, 47(2-4), 122-134

Carey M (2008) Disasters, development, and glacial lake control in twentieth-century Peru. In Wiegandt E ed. Mountains: sources of water, sources of knowledge. Springer, Dordrecht, 181-196

Carey M, Huggel C, Bury J, Portocarrero C and Haeberli W (2012) An integrated socio-environmental framework for glacier hazard management and climate change adaptation: lessons from Lake 513, Cordillera Blanca, Peru. Climatic Change, 112(3-4), $733-767$

Catani F, Casagli N, Ermini L, Righini G and Menduni G (2005) Landslide hazard and risk mapping at catchment scale in the Arno River basin. Landslides, 2(4), 329-342 (doi: 10.1007/ s10346-005-0021-0) 
Clague JJ and Evans SG (2000) A review of catastrophic drainage of moraine-dammed lakes in British Columbia. Quat. Sci. Rev., 19(17-18), 1763-1783 (doi: 10.1016/S0277-3791(00)00090-1)

Davidson R and Lambert K (2001) Comparing the hurricane disaster risk of U.S. coastal counties. Natur. Hazards Rev., 2(3), 132-142 (doi: 10.1061/(ASCE)1527-6988(2001)2:3(132))

Dussaillant A, Benito G, Buytaert W, Carling P, Meier C and Espinoza F (2010) Repeated glacial-lake outburst floods in Patagonia: an increasing hazard? Natur. Hazards, 54(2), 469-481 (doi: 10.1007/s11069-009-9479-8)

Fell R (1994) Landslide risk assessment and acceptable risk. Can. Geotech. J., 31(2), 261-272

Fread DL (1984a) BREACH: an erosion model for earthen dam failures. Hydrologic Research Laboratory, National Weather Service, National Oceanic and Atmospheric Administration, Silver Spring, MD

Fread DL (1984b) DWOPER: National Weather Service operational dynamic wave model. (Hydro technical note) Hydrologic Research Laboratory, National Weather Service, National Oceanic and Atmospheric Administration, Silver Spring, MD

Fread DL (1988) The NWS DAMBRK model: theoretical background/user documentation. Hydrologic Research Laboratory, National Weather Service, National Oceanic and Atmospheric Administration, Silver Spring, MD

Frey H, Haeberli W, Linsbauer A, Huggel C and Paul F (2010) A multi-level strategy for anticipating future glacier lake formation and associated hazard potentials. Natur. Hazards Earth Syst. Sci. (NHESS), 10(2), 339-352

Gardelle J, Arnaud Y and Berthier E (2011) Contrasted evolution of glacial lakes along the Hindu Kush Himalaya mountain range between 1990 and 2009. Global Planet. Change, 75(1-2), 47-55 (doi: 10.1016/j.gloplacha.2010.10.003)

Haeberli W (2013) Mountain permafrost - research frontiers and a special long-term challenge. Cold Reg. Sci. Technol., 96, 71-76 (doi: 10.1016/j.coldregions.2013.02.004)

Huggel C, Kääb A, Haeberli W, Teysseire P and Paul F (2002) Remote sensing based assessment of hazards from glacier lake outbursts: a case study in the Swiss Alps. Can. Geotech. J., 39(2), 316-330

Huggel C, Haeberli W, Kääb A, Bieri D and Richardson S (2004) An assessment procedure for glacial hazards in the Swiss Alps. Can. Geotech. J., 41(6), 1068-1083

Iturrizaga L (2009) Glacial lakes in the Hindukush-Karakoram Mountains and their hazard potential. Geophys. Res. Abstr., 11, EGU2009-8062-1

Ives JD, Shrestha RB and Mool PK (2010) Formation of glacial lakes in the Hindu Kush-Himalayas and GLOF risk assessment. International Centre for Integrated Mountain Development, Kathmandu

Kaltenborn BP, Nellemann C and Vistnes II eds (2010) High mountain glaciers and climate change: challenges to human livelihoods and adaptation. UN Environment Programme, Arendal

Kattelmann R (2003) Glacial lake outburst floods in the Nepal Himalaya: a manageable hazard? Natur. Hazards, 28(1), 145-154 (doi: 10.1023/A:1021130101283)

Klimeš J (2012) Geomorphology and natural hazards of the selected glacial valleys, Cordillera Blanca, Peru. AUC Geogr., 47(2), 25-31

Korup $\mathrm{O}$ and Tweed $\mathrm{F}$ (2007) Ice, moraine, and landslide dams in mountainous terrain. Quat. Sci. Rev., 26(25-28), 3406-3422 (doi: 10.1016/j.quascirev.2007.10.012)

Linsbauer A, Paul F and Haeberli W (2012) Modeling glacier thickness distribution and bed topography over entire mountain ranges with GlabTop: application of a fast and robust approach. J. Geophys. Res., 117(F3), F03007 (doi: 10.1029/2011JF002313)

Linsbauer A, Paul F, Machguth H and Haeberli W (2013) Comparing three different methods to model scenarios of future glacier change in the Swiss Alps. Ann. Glaciol., 54(63 Pt 2), 241-253 (doi: 10.3189/2013AoG63A400)

Liu X, Zhang J, Tong Z, Bao Y and Zhang D (2011) Grid-based multi-attribute risk assessment of snow disasters in the
Grasslands of Xilingol, Inner Mongolia. Human Ecol. Risk Assess., 17(3), 712-731 (doi: 10.1080/10807039.2011.571123) McKillop RJ and Clague JJ (2007) Statistical, remote sensing-based approach for estimating the probability of catastrophic drainage from moraine-dammed lakes in southwestern British Columbia. Global Planet. Change, 56(1-2), 153-171 (doi: 10.1016/ j.gloplacha.2006.07.004)

Mayer C, Lambrecht A, Hagg W, Helm A and Scharrer K (2008) Post-drainage ice dam response at Lake Merzbacher, Inylchek Glacier, Kyrgyzstan. Geogr. Ann. A, 90(1), 87-96 (doi: 10.1111/ j.1468-0459.2008.00336.x)

Mool PK, Bajracharya SR and Joshi SP (2001) Inventory of glaciers, glacial lakes and glacial lake outburst floods: monitoring and early warning systems in the Hindu Kush-Himalayan region, Nepal. International Centre for Integrated Mountain Development with United Nations Environment Programme/Regional Resource Centre for Asia and the Pacific, Kathmandu

Mool, P., Shrestha R and Ives JD (2010) Glacial lakes and associated floods in the Hindu Kush-Himalayas. (Information Sheet 2/10) International Centre for Integrated Mountain Development, Kathmandu

Nadim F and Kjekstad O (2009) Assessment of global high-risk landslide disaster hotspots. In Sassa $\mathrm{K}$ and Canuti $\mathrm{P}$ eds. Landslides - disaster risk reduction. Springer, Berlin, 213-221

Nayar A (2009) When the ice melts. Nature, 461(7267), 1042-1046 (doi: 10.1038/4611042a)

O'Keefe P, Westgate K and Wisner B (1976) Taking the naturalness out of natural disasters. Nature, 260(5552), 566-567 (doi: 10.1038/260566a0)

Osti R and Egashira S (2014) Hydrodynamic characteristics of the Tam Pokhari glacial lake outburst flood in the Mt Everest region, Nepal. Hydrol. Process., 23(20), 2943-2955 (doi: 10.1002/ hyp.7405)

Richardson SD and Reynolds JM (2000) An overview of glacial hazards in the Himalayas. Quat. Int., 65-66(1), 31-47 (doi: 10.1016/S1040-6182(99)00035-X)

Saaty TL (1977) A scaling method for priorities in hierarchical structures. J. Math. Psychol., 15(3), 234-281 (doi: 10.1016/ 0022-2496(77)90033-5)

Sakai A, Chikita K and Yamada T (2000) Expansion of a morainedammed glacial lake, Tsho Rolpa, in Rolwaling Himal, Nepal Himalaya. Limnol. Oceanogr., 45(6), 1401-1408

Schaub Y, Haeberli W, Huggel C, Künzler M and Bründl M (2013) Landslides and new lakes in deglaciating areas: a risk management framework. In Margottini C, Canuti P and Sassa K eds. Landslide science and practice, vol. 7: Social and economic impact and policies. Springer, Berlin, 31-38

Shi Y, Liu C, Wang Z, Liu S and Ye B eds (2005) A concise glacier inventory of China. Shanghai Science Popularization Press, Shanghai [in Chinese]

Singh P and Singh VP (2001) Snow and glacier hydrology. (Water Science and Technology Library) Kluwer Academic Publishers, Boston, MA

Smith K (2001) Environmental hazards: assessing risk and reducing disaster. Routledge, London

Stallings RA (1991) Disasters as social problems? A dissenting view. Int. J. Mass Emergencies Disasters, 9(1), 69-74

Starmap Publishing House (2006) Atlas of China traffic. Starmap Publishing House, Beijing [in Chinese]

Vuichard D and Zimmermann M (1987) The 1985 catastrophic drainage of a moraine-dammed lake, Khumbu Himal, Nepal: cause and consequences. Mt. Res. Dev. [China], 7(2), 91-110

Wang S and Zhao J (2011) Potential evaluation and spatial development strategies of glacier tourism in China. Geogr. Res., 30(8), 1528-1542 (doi: 10.11821/yj2011080018) [in Chinese with English summary]

Wang S and Zhang T (2013) Glacial lakes change and current status in the central Chinese Himalayas from 1990 to 2010. J. Appl. Remote Sens., 7(1), 073459 (doi: 10.1117/1.JRS.7.073459) 
Wang S, Qin D and Ren J (2012) Progress and prospect in risk assessment of glacial lake outburst hazards. Adv. Water Sci., 23(5), 735-742 (doi: 32.1309.P.20120824.1607.017) [in Chinese with English summary]

Wang W, Yao T, Gao Y, Yang X and Kattel DB (2011) A first-order method to identify potentially dangerous glacial lakes in a region of the southeastern Tibetan Plateau. Mt. Res. Dev., 31(2), 122-130 (doi: 10.1659/MRD-JOURNAL-D-10-00059.1)

Wilhite DA (2000) Drought as a natural hazard: concepts and definitions. In Wilhite DA ed. Drought: a global assessment. Routledge, London, 3-18

Wisner B, Blaikie P, Cannon T and Davis I (2004) At risk: natural hazards, people's vulnerability and disasters, 2nd edn. Routledge, London

Worni R, Stoffel M, Huggel C, Volz C, Casteller A and Luckman B (2012) Analysis and dynamic modeling of a moraine failure and glacier lake outburst flood at Ventisquero Negro, Patagonian Andes (Argentina). J. Hydrol., 444-445, 134-145 (doi: 10.1016/ j.jhydrol.2012.04.013)

Worni R, Huggel C and Stoffel M (2013) Glacial lakes in the Indian Himalayas - from an area-wide glacial lake inventory to on-site and modeling based risk assessment of critical glacial lakes. Sci. Total Environ., 468-469(Suppl.), S71-S84 (doi: 10.1016/j. scitotenv.2012.11.043)

Wu C-H and Chen S-C (2009) Determining landslide susceptibility in Central Taiwan from rainfall and six site factors using the analytical hierarchy process method. Geomorphology, 112(3), 190-204 (doi: 10.1016/j.geomorph.2009.06.002)

Yao T (2010) Glacial fluctuations and its impacts on lakes in the southern Tibetan Plateau. Chinese Sci. Bull., 55(20), 2017 (doi: 10.1007/s11434-010-4327-5) [in Chinese with English summary]

Zhang J (2004) Risk assessment of drought disaster in the maizegrowing region of Songliao Plain, China. Agric., Ecosyst. Environ., 102(2), 133-153

Zhang J, Liang J, Liu X and Tong Z (2009) GIS-based risk assessment of ecological disasters in Jilin Province, Northeast China. Human Ecol. Risk Assess., 15(4), 727-745 (doi: 10.1080/ 10807030903050962)

Zhao $\mathrm{Y}$ and others (2006) Assessing the ecological security of the Tibetan Plateau: methodology and a case study for Lhaze County. J. Environ. Manag., 80(2), 120-131 (doi: 10.1016/ j.jenvman.2005.08.019)

MS received 20 May 2014 and accepted in revised form 25 September 2014 